\title{
"Há 200 anos era a mesma coisa": entrevista com Beatriz Bracher
}

Por Christian Grünnagel ${ }^{1}$ e Doris Wieser ${ }^{2}$

\section{O que significa ser homem ou ser mulher para você?}

$\mathrm{Eu}$ acho que uma das coisas que mais diferenciam uma pessoa da outra é ou ela "ser homem" ou ela "ser mulher". Não sei se é importante para o caráter, mas é importante para a maneira emocional de funcionar, a maneira de cognição - o que não quer dizer inteligência. Imagino que existam diferenças, por exemplo, na percepção espacial, como a maioria das mulheres e a maioria dos homens localiza as coisas em geral, e seu próprio corpo, no espaço. Eu acho que a questão da construção de gênero é muito importante e é absolutamente real. Mas a construção de gênero atua sobre uma base genética, quer dizer, quando falamos em construção de gênero a gente não pode ignorar que existe uma base fisiológica. Mas, talvez, o mais importante no que nós somos, e em nossas diferenças, seja essa base, sobre a qual se constrói culturalmente o gênero, dentro de um contexto específico. Quer dizer, as características genéticas se manifestam apenas em dado ambiente, e não no vazio, e esse ambiente é a cultura da época, construída e transformada ao longo de séculos. Temos que ver o que é ser homem ou mulher no Brasil em 2013. Para responder bem, eu acho que a pergunta deve se completar. Eu tenho 52 anos, sou branca, de uma determinada classe social, de São Paulo e mulher. Isso tudo é bastante específico.

\section{Tudo isso junto forma a personalidade da pessoa.}

Sim, do que é ser homem, do que é ser mulher. E eu acho que, na maneira como eu sou escritora, não existe muita diferença entre ser mulher ou homem, no sentido do que eu faço, de como eu penso, no sentido das minhas possibilidades de trabalho, de atuação. Talvez o

\footnotetext{
${ }^{1}$ Doutor em letras românicas e professor do Instituto de Filologia Românica da Universidade de Giessen, Giessen, Alemanha. E-mail: christian.gruennagel@ romanistik.uni-giessen.de

${ }^{2}$ Doutora em literatura ibero-americana e professora do Instituto de Filologia Românica da Universidade de Göttingen, Göttingen, Alemanha. Atualmente bolsista de pós-doutorado da Fundação Alexander von Humboldt na Universidade de Lisboa. E-mail: doris.wieser@phil.unigoettingen.de
} 
sentimento de responsabilidade que eu tenho com a família seja bastante diferente de um sentimento de responsabilidade que um homem da minha geração tem em relação à família. O que já muda na geração dos meus filhos.

\section{Vai mudando...}

É, eu acho que vai mudando. E tem coisas que eu não sei se vão mudando porque não sei até que ponto é cultural ou não é. Eu acho que isso é bem difícil de a gente saber. Particularmente eu sou muito apegada à família e tendo a achar que isso é uma questão feminina, mas não estou segura que seja. Apegada de um jeito que às vezes priorizo isso em relação a outras coisas. Acho que no Brasil, na minha classe, hoje em dia, seria uma das coisas que diferencia o homem da mulher. $\mathrm{O}$ fato de a mulher abdicar de outras coisas ou priorizar a família quando sente que a família precisa dela.

Quer dizer que para os homens em geral a família não tem tanta importância?

Eu acho que tem importância, sim, mas o homem vai dar um jeito de conciliar os dois. Para ele é mais óbvio que tem que ser conciliável. A mulher tende rapidamente a abrir mão, enfim. Acho que ela tem culpa. Ela vai tomar conta da família e depois ver como ela vai fazer o trabalho. Pode ser uma coisa minha e não tanto da mulher em geral.

Em sua opinião, que importância ainda tem o machismo atualmente no Brasil?

De novo, faz muita diferença a classe a que você pertence e o lugar em que você mora. Por exemplo, entre os escritores, eu acho que tenho sido muito favorecida por ser mulher, porque as pessoas que organizam os festivais de literatura têm cuidado em convidar muitas mulheres, para não serem acusados de que é um festival apenas de homens. E como não são muitas as mulheres escritoras, as poucas são bastante chamadas, eu, inclusive. Como comecei a escrever mais velha, eu acho que tenho uma certa segurança de que sou uma boa escritora, mas, se eu fosse mais insegura, acharia que só sou chamada porque sou mulher. 
Quer dizer então que o mercado literário no Brasil ainda é dominado por homens?

Eu fiz parte do júri de um concurso de uma revista para jovens autores e tivemos mais ou menos $70 \%$ de homens escolhidos e $30 \%$ mulheres. Houve uma acusação na imprensa de que teríamos favorecido os homens. Eu era a única jurada mulher e pensei: "Será que eu favoreci os homens?". Ao ver o número de originais que tinham sido mandados, eu me dei conta de que não é que haja um machismo das editoras, ao preferirem os autores homens às autoras mulheres, é que as autoras mulheres escrevem menos, mandam menos originais. Quase exatamente $70 \%$ dos originais mandados para a revista eram de autores homens, e 30\%, de mulheres. Então, não acho que exista machismo na hora de selecionar. As mulheres têm menos coragem na hora de escrever, talvez sejam menos incentivadas a escrever. Mas, na hora em que elas escrevem, eu acho que existe, da parte das editoras, disposição de publicá-las, e são avaliadas assim como os homens. Porque aí tem um nível intelectual, no qual o machismo é muito menor. Se você for para as classes mais baixas, acontece de o machismo ser muito violento. De matar mesmo, espancar, violento não só culturalmente, mas nas vias de fato. Ao mesmo tempo, há muitas mulheres que sustentam a família, mulheres que ganham seus salários e cuidam dos filhos, porque os homens têm filhos e abandonam os lares. Eu não sei quantos, mas muitos lares no Brasil são sustentados pelas mulheres. Então, é curioso, há um machismo muito grande, mas por outro lado são as mulheres que sustentam as famílias. E de novo um caso pessoal meu: na minha família somos cinco filhos. As duas mulheres são artistas. Eu sou escritora e a minha irmã é escultora, e sinto que no nosso caso meu pai não se importou com isso. Mas, se meus irmãos quisessem ser artistas, ele teria ficado muito preocupado. Os meninos precisavam ganhar dinheiro para sustentar a família; as mulheres, tudo bem, porque provavelmente iriam se se casar e o marido é quem deveria ganhar o dinheiro.

As filhas tiveram mais liberdade para virarem artistas do que os filhos.

Uma vida mais livre. É curioso: foi o machismo que nos deu a liberdade.

É possível se sustentar sendo escritora? 
Não. Não é possível. No meu caso eu tenho dinheiro de família e é com ele que me sustento. $\mathrm{O}$ que eu percebo dos meus colegas escritores conhecidos e reconhecidos é que são chamados para escrever artigos de jornal, críticas de livros, dar palestras, ganham dinheiro com isso e conseguem viver com o trabalho deles. Mas não da venda dos livros. Então eles dizem que estão vivendo como escritores, mas eu não acho precisa essa afirmação. Eles estão vivendo como resenhistas, como colunistas de jornal, palestrantes, não como escritores de ficção.

Já falamos um pouco sobre a masculinidade da classe média, da classe alta, em comparação com a masculinidade rural ou da periferia. Há um modelo de uma socióloga australiana, Connell, que propõe pensar a masculinidade no plural, ou seja, masculinidades. ${ }^{3}$ Você diria também que há várias masculinidades no Brasil?

Deixa eu só falar uma coisa antes, já que você falou do rural. Minha irmã, que é escultora, chama-se Elisa Bracher, trabalha com esculturas de madeira enormes. O estúdio dela é muito grande também e é numa área mais pobre, para ter o tamanho de terreno que precisa.

\section{Onde fica?}

Fica em São Paulo, num bairro chamado Vila Leopoldina, e tem umas favelas perto. As crianças da favela e de um conjunto habitacional passavam ali para ir à escola pública. Elas ficaram curiosas, minha irmã as chamou para entrar e, enfim, ela e o assistente começaram a dar aulas de marcenaria dez anos atrás. E hoje cem crianças têm oficina de marcenaria, de artes, de capoeira, de culinária. É uma coisa muito bonita. E são muitas crianças cujas famílias vêm do Nordeste. A Elisa fez um vídeo sobre linguagem, ela viajou para a Inglaterra, foi para a Índia e, principalmente, para as cidades de onde vinham as crianças. Quando você é do Nordeste e vai para São Paulo, quase tem que aprender uma outra língua, apesar de ser o português - é uma questão de identidade e de linguagem. No vídeo também tem depoimentos sobre a escrita. Quando você aprende a escrever, muda um pouco a identidade. Tem depoimentos de moças de 25 anos que diziam que os pais - ao contrário do meu caso - deixavam para os meninos

\footnotetext{
${ }^{3}$ Para mais detalhes sobre o enfoque teórico de Connell, veja-se o texto de apresentação deste dossiê de entrevistas.
} 
aprenderem a ler, e as meninas, não, porque as meninas, se aprendessem a ler, iam escrever cartas para os namorados.

\section{É uma maneira de controlar...}

É... Eu achei curioso isso. Parece coisa da Idade Média, né? Mas é de hoje em dia, muito recente.

Quer dizer que há uma masculinidade especial da favela, da periferia, que é diferente da masculinidade da classe média.

É. Há meninas de 17 anos, meninas que vão para escola, que ouvem rap, funk, que veem novela. Mas você começa a perguntar e vê que os meninos têm uma ligação com a profissão, querem logo ter uma profissão ou entrar para o tráfico de drogas. Essa favela específica é muito pobre, $80 \%$ das famílias são ligadas ao sistema prisional, ou seja, têm algum parente que está preso. O tráfico de drogas é muito influente lá dentro. Então os meninos com 15, 16 anos estão procurando uma maneira de arrumar dinheiro, arrumar bolsas, estágios, porque pela lei eles não podem trabalhar aos 16 anos, só aos 18 não podem ter um trabalho de tempo integral remunerado. $\mathrm{O}$ tráfico de drogas os pega muito cedo. Então, para saírem de casa cedo, os meninos ou vão para o tráfico de drogas ou tentam arrumar um trabalho; e as meninas engravidam, porque engravidar é uma maneira de elas saírem de casa. É uma coisa muito, muito antiga. Há 200 anos era a mesma coisa. Então você nota uma camada da população em que, apesar de tudo ter mudado, nada mudou, apesar de ela ter contato com tantas coisas diferentes.

Com música popular, com funk, tudo isso, mas não muda muito...

E com toda uma cultura de cinema americano, que passa pela televisão, com as novelas que, boas ou péssimas, trazem muitas maneiras diferentes de ser.

E tem também a homossexualidade que aparece nas novelas. Qual é o estado atual da homossexualidade no Brasil?

É uma coisa que tem se falado muito. Nas novelas aparecem personagens homossexuais, tem a parada gay em São Paulo, que é a 
maior parada gay do mundo. Em São Paulo, na Consolação, você tem uma coisa mais explícita, gays andando de mãos dadas, e a TV Globo tem quadros educativos em relação à homofobia. Mas eu percebo que é uma coisa muito insuportável para algumas pessoas. A homofobia é mais forte do que o racismo no Brasil, muito, milhões de vezes mais. Talvez porque sejamos tão misturados. Acho que o racismo no Brasil é uma coisa muito específica em relação, por exemplo, ao emprego, quando você prefere dar emprego a uma pessoa branca a dá-lo a uma pessoa preta, quando você não vai se casar com uma pessoa preta, coisas assim. Mas já quanto à homofobia: tem pessoas que não aguentam ver um homossexual, uma pessoa com trejeitos. A pessoa sente que aquilo é moralmente errado. Por exemplo, com os ateus: a pessoa que é evangélica - e talvez católica - acha que se alguém é ateu, aquilo é um problema de caráter, que ele deve ser mau. Em relação à homossexualidade, às vezes é isso: pensam que a pessoa é uma pessoa errada. Eu me lembro de um diálogo que tive com os marceneiros do Instituto Acaia, o instituto que minha irmã, Elisa, criou, ${ }^{4}$ que procura fazer esse trabalho com respeito às diferenças, e eles falaram: "Ah, a gente sabe, a gente entende". Porque lá uma das questões é que as famílias são muito desestruturadas e há a prostituição infantil e o abuso de crianças. Há crianças de oito anos abusadas, e meninos abusados pelo padrasto, uma coisa perversa. Os marceneiros, então, diziam que não se deveria levar a mal um adolescente homossexual porque eles não tinham culpa, era uma doença com a qual eles nasciam. E eu disse que não, homossexualismo não é uma doença. E um deles me perguntou: "Não? Então é safadeza, mesmo?". Eu acho que a homossexualidade é muito considerada como um problema que uma pessoa tem e que ela precisa resolver. A maior parte das pessoas ou tem raiva ou tem pena: "Coitado do homossexual".

Você acha que existe a mesma fobia contra casais lésbicos e contra homens gays?

Não, existe muito mais contra homens que contra mulheres.

4 A apresentação do Instituto Acaia está disponível em: <http://www.acaia.org.br/quemsomos/historico/>. 


\section{Você acha que as novelas possam mudar um pouco essa postura?}

Sim, eu acho que está mudando. Em primeiro lugar eu acho que hoje em dia tem muitas pessoas que não são tão agressivas, elas estão se esforçando para aceitar, mas a maneira de aceitarem é achar que a pessoa tem um problema que precisa ser compreendido. E não: "Essa pessoa é feliz!". Vai demorar. Eu acho que tem um perigo: a televisão está tentando criar um clima de normalidade, muitos homossexuais estão assumindo mais sua homossexualidade, e isso, às vezes, está gerando mais agressividade. Como há pessoas que continuam não aceitando, às vezes, me dá a impressão de que está havendo mais agressões, mais brigas e mesmo assassinatos do que antes.

\section{Mas as mulheres homossexuais continuam sendo quase invisíveis...}

$\mathrm{Eu}$ acho que é porque o carinho entre mulheres sempre existiu, mesmo entre mulheres não homossexuais. Então quando você vê mulheres de mãos dadas, abraçadas, ou mesmo uma agradando a outra, você não sabe se elas são namoradas ou não. Não é uma coisa que você logo olha. Com homens é diferente. É algo que seu olho fala: "Há algo estranho". Mesmo que você não vá achar ruim nem nada, é uma coisa que chama a atenção. Aí você pode falar "São dois namorados e pronto" ou dizer o mesmo de forma alterada, irritada. Mas, com relação à mulher, não é uma coisa que você olha como algo diferente.

E eu sinto uma coisa que é curiosa. Sempre quem é mais afetado é o homem heterossexual, sendo que a mulher heterossexual não se sente afetada, nem pela homossexualidade feminina, nem pela homossexualidade masculina. Ou sente menos.

O que eu sinto também é que no Brasil, entre os mais jovens da classe média, as pessoas são talvez muito mais abertas a relacionamentos bissexuais. Não tanto os homens, mas as mulheres. E na classe mais baixa eu não sei o que dizer, a verdade é que eu não conheço a classe pobre. O que eu conheço vem do meu convívio no Instituto Acaia, onde eu trabalhei algumas vezes e onde os alunos são muito pobres mesmo. Eu conheço ou a classe média ou a classe muito pobre; há um espaço entre um e outro com o qual eu não convivo. 
Hoje em dia os homens da classe média são muito mais participativos nas tarefas antigamente femininas. E sem nenhum exibicionismo. Na minha geração os homens já ajudavam muito em casa. Meu marido me ajudou a cuidar dos filhos. Mas sempre havia um certo: "Veja! Eu estou ajudando". E hoje em dia eles não ajudam, fazem, tanto quanto as mulheres.

Como escritora, você trabalha de uma maneira diferente para criar um personagem feminino ou masculino, um "Antônio", por exemplo?

Não. Isso é o que eu acho curioso. Até escrevi um texto sobre isso, sobre se a literatura feminina existe. Eu não sinto diferença nenhuma em criar um personagem masculino, um feminino, uma criança ou adulto. Eu sinto diferença no personagem específico, em cada um, mas não pelo gênero dele ou pela idade. Porque às vezes tenho dificuldade e reflito se aquele personagem está convincente ou não, mas com qualquer um que seja diferente de mim eu tenho essa dúvida. Ou porque é mais velho, ou porque é mais jovem, ou porque é carioca, ou porque é alemão. Eu sempre fico muito insegura: será que um homem falaria isso, será que uma criança falaria dessa maneira? Penso que a literatura é tão cultural, e a matéria-prima da literatura é tão a literatura ela mesma, que esta é uma das razões de o gênero do autor não afetar o resultado. São muitos os livros que eu li e os meus personagens são, em grande parte, tirados de outros personagens que li. E mesmo a maneira de eu compreender é assim; por exemplo, a minha mãe é baseada nas mães que eu li em livros, nas referências literárias e cinematográficas que eu já tenho de mães. Os homens são baseados nos homens que eu já li. E mesmo eu. Os sentimentos que expresso de mim de certa maneira são os que li expressos em livros.

\section{Quer dizer que não há uma escritura feminina?}

Acho que não. Eu definitivamente não acredito nisso.

Eu gostei muito dos seus contos com o título Meu amor. Parece-me uma escritura muitas vezes experimental, às vezes são textos muito breves e eu me pergunto se se trata de contos, microcontos ou já de poemas em prosa.

Eu não considero que eu escreva microcontos. Essa definição de microcontos, a primeira vez que ouvi, foi de Marcelino Freire. Eu não 
sei se já existia antes dele. E há contos do Marcelino que são de uma frase, são contos realmente pequenininhos. A Wanda Jakob e a Luísa Costa organizaram uma coleção que elas chamaram de microcontos e publicaram contos meus. ${ }^{5}$

Considero que o que eu escrevo é conto. E nada é poema ou poema em prosa, nem novela. Eu acho que cada gênero - poesia, conto, romance, teatro, crônica - carrega não só a forma dele mas também um conteúdo específico. Ou uma intencionalidade específica, um contrato com o leitor que é próprio de cada gênero. Quando escrevo um poema, ele tem a forma de poema, escrito em versos, mas acho que também tem uma intenção que apenas a poesia carrega. O poema lírico tem um compromisso de verdade. "Eu vou dizer a verdade". É um eu narrativo muito diferente daquele do conto. $\mathrm{O}$ narrador de um conto já é bem parecido com o de um romance. $\mathrm{O}$ eu narrativo de um poema, que não chamamos de narrador, mas de eu-lírico, é quase o próprio autor, mesmo que seja uma mentira, é uma mentira contada pelo narradorautor, e não por um narrador-personagem. Ele vai abrir o coração, mesmo que não abra; é o que o formato poesia diz que acontece. Eu acho que tem uma coisa muito íntima, quer dizer, uma persona, não exatamente ele, mas muito próximo a ele. O de uma crônica, por exemplo, também é o autor, mas de forma mais coloquial, ele até usa o nome dele, isso tudo. Quando eu começo a escrever um conto, é quase sempre uma ideia só, eu não vou fazer muitas digressões, mesmo que não seja um episódio só. Um romance é mais sujo, eu quero que seja sujo. Mesmo que não seja, eu tenho essa intenção, existe a possibilidade de ser. Se eu misturar um poema num conto, eu estou misturando essa intenção do poema no conto. Então, quando se fala que não existem fronteiras entre os gêneros, eu discordo, porque, quando não houver mais as fronteiras, não vai ter mais a mistura de intenção. Quando eu misturo, eu misturo mantendo as diferenças. É como quando você mistura na culinária o açúcar e sal, por exemplo; você quer que se continue sentindo o gosto do açúcar e o gosto do sal. Se você fala que não tem diferença, é porque um gênero nada acrescenta ao outro, quando colocados na mesma obra. Então, o microconto eu não sei o que

\footnotetext{
${ }^{5}$ HÖLZL, Luísa Costa (Org.). Microcontos. Tradução de Wanda Jakob. Munique: DTV, 2013. Este livro bilíngue (alemão-português) contém os seguintes contos de Beatriz Bracher: "Ele gostava de Maria", "Raza" e "Duas fotografias sobre o natural".
} 
é. Eu acho que é coisa de você ter uma ideia muito rápida e prender tudo em uma imagem só, em uma frase só. É muito condensado e sem evolução de uma narrativa, e acho que todos os meus contos têm uma evolução, mesmo o primeiro, "Ele gostava de Maria".

\section{Que também é muito belo e muito curto.}

Mas eu acho que tem uma historinha, um desenvolvimento.

Falemos um pouco sobre o título da coleção, Meu amor. Penso que poderia se referir ao último conto escrito em inglês, "My love", dedicado a sua mãe, e na nota de autora você nos informa que "a reunião destes contos forma uma história única que encerra seu próprio destino". Você escolheu o título Meu amor para indicar o tema central da coleção? Que relação há entre o título e os contos?

É curioso porque "Meu amor" é um poema em uma antologia de contos, tem a ver com o que estávamos dizendo. O livro é dedicado à minha mãe e o poema também é dedicado à minha mãe. Mas o livro eu dedico com o nome dela e o poema eu dedico dizendo "mãe". Eu nunca tinha pensado nisso, que é a mesma pessoa mas de maneiras diferentes. E é um livro de contos sob a luz da poesia, de uma certa verdade autoral, que eu falei na outra resposta. Não tinha pensado nisso. Talvez o que mais tenha de poético seja esse "eu narrador" que quer ser mais do que um personagem. Acho que é isso. Na verdade muitos desses contos eu escrevi em épocas diferentes, e quando fui rever vi que tinha um conjunto temático. O tema que perpassa tudo é a questão da intimidade. Todos têm a intimidade em sua trama, no sentido de intensidade da relação, não de conhecimento profundo. Porque nós podemos falar que alguém é íntimo porque nos conhece há muito tempo, mas você pode dizer também que é íntimo porque teve um momento intenso em que foi obrigada, ou quis, se abrir de forma a revelar a sua intimidade.

O amor nessa coleção não é um amor romântico. Parece que às vezes há uma sexualidade violenta. Nesse sentido, é um amor mais moderno?

Não, eu não acho que é mais moderno, mesmo porque acho que tem muito a ver com violência, com conhecimento profundo. Violência quase no sentido de sangue se misturando com sangue. E também tem 
muita a coisa do piegas, do clichê - acho que é uma outra constante do livro. A própria expressão "meu amor" é piegas, cafona. E tem um conto, o "Ficção", no qual o assaltante dá um soco na motorista que acha que está num carro blindado, e não está, e o revólver dele é de brincadeira, aí ele soca e quebra o vidro, dá um soco na moça e deixa seu revólver no colo dela. Acaba com algo como "Ficou no colo os nossos sangues". O editor falou: "Isso é meio piegas. Por que você não fala 'o sangue'? Por que 'os nossos sangues'? Você não precisa falar isso, já fica claro...". Mas eu queria essa coisa exagerada, fora de medida, de quem não sabe muito falar, por isso precisa usar uma palavra que já foi falada, porque não tem palavras próprias, o que não quer dizer que não seja sincero aquilo. Como você vai falar "Eu te amo" de outra maneira se é exatamente isso que você quer expressar?

Eu penso que há também personagens nesses contos que têm uma linguagem muito pessoal, por exemplo, o João, que está na prisão e está sonhando com sua antiga professora. Há uma imagem muito interessante, muito perturbadora também: a imagem do pequeno beija-flor, que pica os olhos da professora para que ela fique cega. E parece que é uma violência lírica, ou é também kitsch, o clichê?

Não, não, eu acho que é lírica. É claro que eu quero que meus contos tenham sido originais, que eu tenha sido capaz de atingir algo novo. Por exemplo, nesse conto, "João", a mãe dele quando chega lá diz: "Nunca imaginei ver meu filho numa situação dessas". É isso que essas moças falam, uma frase feita, o que chamamos de clichê. Agora, para tudo aquilo que essa mãe queria falar, ela não tinha outras palavras. Essa mãe está sofrendo muito porque trabalhou a vida inteira e o filho foi pego roubando. O coração dela está partido. Só que todas as frases que ela diz são frases feitas. Mas ninguém duvida que ela está sofrendo.

A questão desse menino é que ele sabia escrever, ele sabia ser original com as palavras. Talvez esse conto seja o cerne de todo o livro, João se sobressaía no meio dele, em que as pessoas quando falam com um universo diferente do seu, com um outro meio, falam frases feitas. Ele sabia que era a mesma coisa, porque todo ser humano é a mesma coisa. Mas o olhar da professora dizia que ele era diferente, era a sua maneira de elogiá-lo, e, por isso, ele se sentia traindo a mãe, porque a professora colocava-o acima dela. Tinha raiva de ser valorizado, porque isso era feito em comparação a seus amigos e pais, para valorizar o domínio de 
uma determinada linguagem, se desvaloriza os que não têm esse domínio. E há todo esse sentimento de traição. O livro é uma traição. E o livro é dedicado à minha mãe. Então quando você fala da violência como uma coisa muito moderna, ligada ao amor, eu vejo como uma coisa bíblica. Porque eu acho que a traição está na origem do amor no sentido de você querer ser um, quer se diferenciar, ser especial para poder se unir ao outro. Para isso precisa negar tudo o que não seja aquele amor.

Falando ainda da violência, há certos autores brasileiros que representam um pouco essa faceta. A violência é uma temática que vende bem na Europa. Estou pensando na literatura da Patrícia Melo, do Luís Ruffato e também da literatura marginal do Ferréz. Todos eles também falam da violência interfamiliar, entre o homem e a mulher ou entre pais e filhos. Segundo você, qual é a diferença entre a representação da violência na sua literatura e na literatura deles?

Eu nunca li a Patrícia Melo, mas o Ferréz e o Ruffato eu já li. Deixa eu só abrir um parênteses. Eu acho que o Ferréz tem uma coisa muito interessante. Uma vez eu queria que alguém fizesse uma pesquisa sobre as cenas de sexo na literatura brasileira. Pelo menos em Capão Pecado e Manual prático do ódio as pessoas sempre trepam tão rápido, é um sexo tão rápido, tão rápido.

\section{É violento e quase pornográfico...}

Nunca é bom, né? Nunca é gostoso. Sempre que eu leio, eu falo assim: "Poxa vida, nunca pode ser bom?".

A resposta que o Ferréz nos deu foi que na periferia é esse tipo de sexo que as pessoas têm, é uma representação realista.

Seria que nunca é gostoso? Não é possível... E ele parece ser uma pessoa feliz, né? Mas enfim, com o Ferréz eu diria que, apesar de tratar de questões familiares, ele se detém menos ao interior dos personagens, apesar de também ter esse lado. Há muitas angústias que levam aos dramas, às violências, às pessoas estourarem, levando-as a caminhos extremos. Fala-se muito que a minha literatura é intimista, mas o Ferréz tem descrições fortes sobre o que acontece, sobre os sentimentos de humilhação que levam a pessoa a se manifestar da maneira como ela se manifesta. Mas eu acho que 
ele atribui muitas coisas às relações de opressão social, do meio. E as coisas vão mais rápido dentro dos livros dele.

Você diria que a sua literatura é mais psicológica, com mais introspecção nas personagens?

Eu acho que sim. Mais fácil seria dizer assim: a dele é mais externa, a minha é mais interna; a dele tem uma coisa mais "política evidente", a minha tem uma coisa da política mais sutil. Mas, se eu paro para tentar ser mais sincera, vejo que a dele também é psicológica. Eu me lembro de um conto que eu li no blog dele falando de um cara pegando um ônibus. Ele estava suado. E no ônibus tinha um homem encoxando uma mulher, e ele vendo isso. Ele chega no supermercado onde trabalha e o patrão sente e fala do cheiro dele. Então nós vemos como a cabeça do cara vai se transformando, ele vai ficando irritado, e isso é introspectivo também. Então não é que ele não seja sutil. Não é preto ou branco. Mas, realmente, eu acho que fico atormentando mais os meus personagens, e principalmente há mais relações familiares. Na minha literatura a família conta muito, as relações intrafamiliares são muito relevantes, têm um peso grande.

Aparecem muitas mães, pais, filhos, filhas nos contos...

Exatamente, e eu acho que, para o Ferréz as relações das comunidades, entre a comunidade e o patrão, é mais forte. E com o Ruffato há painéis maiores ainda. Ele age muito em blocos. Eu li Mamma, son tanto felice, $O$ mundo inimigo, e Eles eram muitos cavalos. São todos bonitos. Apesar de você perceber as relações familiares, ele tem umas descrições mais secas. A psicologia dele é tratada de outra maneira. Você vai descobrindo o que se passa no interior a partir do que o personagem faz, das ações, e não tanto através de uma descrição mais reflexiva. As cenas são mais rápidas. $\mathrm{Eu}$ acho que ele monta os blocos e é isso que vai criando as intrigas. Então, vamos dizer que eu seja a mais psicológica desses três. E eu acho que a violência política, a violência ideológica, se dá muito dentro dos meus personagens. Eles sofrem por viverem em um mundo dividido, mas não sofrem as consequências disso, pois em geral são de uma classe mais alta. E no caso do Ferréz e do Ruffato, os personagens são de uma classe mais baixa, então esse mundo os maltrata. Eles sofrem as consequências: existe o conflito ali acontecendo em cima deles. 
No conto "Cloc, clac (as crianças, a cidade e a sala)" parece que há uma crítica política. Há três crianças mortas nesse conto, das quais duas morrem por causa da falha da segurança: uma criança com o nome de "Victor Hugo" morre presa num cinto de segurança, e a outra criança morre acidentalmente nas mãos da polícia. Isso é uma alegoria do Estado atual do Brasil, no qual as forças públicas matam?

Eu não percebo uma alegoria, foram mortes que realmente aconteceram. Todos esses crimes aconteceram e foram crimes que me emocionaram muito. Eu fico arrepiada de novo pensando neles. Os dois "Cloc, clac" foram uma mistura de crônica e conto, porque os quatro eventos aconteceram. O segundo "Cloc, clac" é de uma enfermeira batendo em um velho. ${ }^{7}$ E foram coisas muito divulgadas no Brasil, aparecendo na televisão e nos jornais. E eu não pensei como uma alegoria, mas sim como uma coisa mais concreta, a repetição de violência com pessoas mais fracas e de crueldade sem propósito.

Esse caso da enfermeira violenta poderia ser mais chocante por ser uma personagem feminina? Porque "normalmente", segundo os clichês, os homens são os agentes da violência.

Eu nunca tinha pensado nisso que você está falando. Em todos os casos são pessoas que deveriam cuidar. No caso do pai eu tinha pensado e até falo: supõe-se que os pais cuidam. Mas, no caso do cinto de segurança, ele é feito para dar a segurança, no caso da enfermeira é a enfermeira e no último caso é a criancinha que se espanta com o velho, dentro do avião. A criancinha não quer se sentar ao lado do velho. E lá são duas pessoas muito frágeis, uma criança e um velho. E um está fazendo mal ao outro. A menina está expondo a feiura do velho e o velho está assustando a menina. E nenhum dos dois tem culpa.

Eu acho que o romance Antonio é tecnicamente muito interessante, principalmente porque há três vozes. Raul, Haroldo e Isabel, que falam em diferentes capítulos. E todos esses personagens se dirigem a Benjamim, como se ele fizesse um entrevista, mas a voz dele não aparece. Então é quase como se fossem monólogos, mas monólogos dirigidos a um você.

\footnotetext{
${ }^{6}$ BRACHER, Beatriz. Meu amor. São Paulo: 34, 2009. p. 111-123.

7 “Cloc, clac (o velho, o bebê, você, ela e eu)", em Bracher (2009, p. 125-127).
} 
Como surgiu essa ideia e qual foi a intenção em dirigir esse tipo de técnica?

A ideia das três vozes, ou diferentes vozes, é uma ideia que existe muito na literatura. Especificamente essa coisa de nomear os narradores eu me inspirei no Faulkner em As I lay dying. É um livro que se passa no presente e eles fazem uma viagem para enterrar a mãe. Começa com a mãe morrendo, sendo feito o caixão, depois eles levam a mãe para ser enterrada na cidade dos parentes dela. É um livro cheio de peripécias. E não é falado para alguma pessoa. Enfim, eu adoro esse livro. E, tirando a diversidade de narradores, é completamente diferente de Antonio. Na verdade o que eu queria era escrever um livro em terceira pessoa, porque os dois primeiros tinham sido em primeira pessoa, mas é um desafio para mim. Porque eu tenho uma dificuldade que é a seguinte: “Mas por que esse narrador está contando essa história?". E é uma bobagem, porque eu adoro ler livros em que a pessoa não explica nada, é uma história que está sendo contada. Então eu me lembrei do Conrad, que está em um bar, e um marinheiro, no caso de Lord Jim, Marlow, começa a contar uma história. É também o caso de Henry James, em $A$ volta do parafuso, em que um personagem conta uma história para uma audiência específica. Acho que o Tchecov também tem algo assim, uma história dentro da história. E então eu imaginei alguém contando uma história. Foi o Raul. Depois apareceu uma outra voz , "Eu quero que se fale outra coisa que Raul não teria como saber", então eu coloquei a Isabel. Comecei a ver que eu queria que a história fosse um pouco instável, que você não soubesse exatamente se aquilo tinha acontecido ou não. Eu lembrei que o Dostoiévski tem um livro chamado Memórias do subsolo, no qual o narrador é uma pessoa muito ressentida, o tempo inteiro está dizendo que ele se deu mal e os outros se deram bem. Quando eu li esse livro pela segunda vez, percebi que tem um "você", que está sendo acusado pelo narrador, ele vai criando um personagem que é o seu interlocutor e que é o leitor. E eu achei muito interessante porque isso gera um incômodo, você começa a ter uma certa culpa, como se tivesse alguma relação com o que aconteceu com aquela pessoa. Fiquei pensando que aqueles narradores do meu livro estão falando para alguém, mas só que era o contrário: eles tinham culpa em relação àquela pessoa. É como se nenhuma fala fosse inocente, você sempre fala por algum motivo. Eu me dei conta de que eu tinha uma intenção ao escrever esse livro. Parece que as coisas vão acontecendo 
para revelar a mim mesmo porque eu estou escrevendo aquela história. E na verdade é a história da minha geração que eu queria contar para o meu filho. Então, esse livro é um livro que não tem nada de biográfico, talvez até diferente do Azul e dura, que tem alguma coisa de biográfico. É um livro muito inspirado em histórias de amigos e depois eu fui misturando, misturando e acabou assim. A ideia de uma pessoa nascida na década de 1960, que na década de 1970 foi viajar, que estudou nessas escolas e cujos pais haviam sido criados de maneira tradicional e, já adultos, encaram a liberação sexual; ao mesmo tempo tem o convívio com o horror da ditatura militar ainda criança, algo bem geracional.

Outra característica da técnica narrativa desse livro é que o discurso desses três personagens não são muito ordenados. Essa maneira associativa de reconstruir o passado é um intento de retratar a maneira de nossa memória funcionar? Esse quebra-cabeças é uma maneira de descrever como funciona o nosso cérebro?

É um pouco cronológico porque tem a infância do Teo, a ida dele para Minas e depois a chegada dele em São Paulo. Então não é tão complicado, né? $\mathrm{Na}$ verdade as pessoas se queixam. Eu até vi uma crítica aqui da Alemanha escrever que é muito complicado saber quem é filho de quem, quem é quem. O que eu queria com a confusão inicial era mostrar que o Benjamim chegou no meio da história. Quem está ouvindo a história sabe muito pouco. Apesar de ser filho do Teodoro, ele está confuso; ele chega lá porque não conhece a história da família dele. Ele conheceu o pai, mas não sabe quem foi o avô, não sabe o que aconteceu antes do seu nascimento. Ele não sabe que tipo de família era a dele. Não sabe nada e precisa saber. Está aflito e bravo com aquilo, porque, de repente, descobre que é filho de uma mulher que foi casada com o avô dele, além de ser casada com o pai e nunca ninguém tinha falado isso para ele. E eu queria que essa aflição de não saber nada por inteiro e a necessidade de entender passasse para o leitor. O leitor fica bravo porque o leitor é o Benjamim e no começo tudo é confusão. "Ah", me dizem alguns leitores, "eu precisei escrever em um papel, ao lado do livro, quem é quem". Mas o Benjamim provavelmente também precisou quebrar a cabeça para fazer isso. E essa sensação de estar ouvindo uma história que já existia antes de você e você estar pegando ela no meio é exatamente o que está acontecendo com ele. A avó, Isabel, ele a 
conhecia, mas o Raul e o Haroldo, é a primeira vez que ele vai ver. Então essa é a ideia.

\section{Quer dizer então que o leitor compartilha da confusão do Benjamim?}

Exatamente, porque o leitor é o Benjamim, de certa maneira.

E o Benjamim sente uma necessidade muito grande de descobrir esse segredo da família. Eu acho que isso tem a ver com a necessidade dele de saber quem é, uma questão de identidade. Porque não conhecer a história da geração dos pais e dos avós vem a ser um problema para a identidade própria.

Ele vai em busca dessa história porque a tia Leonor diz que a mãe dele também foi mulher do avô. Ele vai atrás da explicação disso tudo. No primeiro capítulo já é o Raul falando: "Você veio aqui só por causa disso. E realmente eu não sabia, só fiquei sabendo agora que você me contou". Logo nas primeiras páginas já é dito, e o leitor demora um pouquinho para entender porque é uma coisa mesmo maluca. O Benjamim vai ter um filho, que é o Antonio, quando contam a ele esse segredo de família; ele vai começar a construir uma família e precisa saber de qual família ele vem, de qual família o filho dele vem. Essa é a sensação de que você nunca está começando nada, que você é a continuação de alguma coisa; de que você pode continuar de uma maneira ou de outra, mas não tem jeito, as coisas não começam em você. Você pode modificar tudo, mas tem que saber o que você está modificando. E a Isabel é muito firme ao falar isso para ele. "Se você veio aqui é porque você não está negando as coisas, porque você está querendo saber o que é". Conhecer a história da família é importante para a identidade dele como pai. Ele vai construir a família, então o filho dele vai ser neto, bisneto e tataraneto dessa história, e ele sente que não tem o direito de negar essa história à família do filho dele. Quer entender, ele tem um pai que enlouqueceu a determinada altura. Você não sabe tudo, mas consegue imaginar porque tudo aquilo aconteceu ouvindo a Isabel. Você imagina que tenha sido uma mãe e uma avó difícil. Mas nós não sabemos direito porque a gente nunca ouve o Benjamim.

A figura da Isabel eu acho interessante porque ela é uma matriarca poderosa, não muito carinhosa. Ela representa algo típico do sistema cultural brasileiro? Em que meio é típico a mãe e a avó terem tanto peso na família brasileira? 
Eu acho que é muito típico do grupo no qual eu fui criada. Eu não sei em que medida ela é típica no sentido mais amplo. Isabel é um tipo específico, que mistura a necessidade de ser uma pessoa polida, educada com a de ser trabalhadora e especial, e que se sobressai. É daí que vem a falta de afeto e a dureza dela. Tem muito a ver com a mistura em São Paulo de imigrantes com brasileiros. Uma classe brasileira que às vezes vem de famílias ricas empobrecidas e de imigrantes pobres que enriqueceram. Essa é a mistura da qual eu e muitas pessoas vêm, na qual o trabalho não é valorizado por uns e muito valorizado pelos outros. Tem esse encontro que é interessante e no qual é importante valorizar o trabalho o tempo inteiro. Aqui na Alemanha parece que é bobagem eu falar isso, porque é claro que todo mundo tem que trabalhar e se esforçar. Mas no Brasil isso não é muito evidente; se você nasce em uma determinada classe parece que as coisas vão chegar para você sem você se esforçar muito. Então é um tipo de matriarcado que tenta unir a coisa antiga e tradicional, de ter a mesa farta, muita comida - que é uma coisa muito de Portugal -, ter a casa cheia, muitos amigos; mesmo quando você não tem dinheiro você faz questão de receber muito bem, com um outro lado de ter disciplina, estudar, trabalhar.

No século XX o tema central da literatura brasileira, em vários movimentos literários, era a brasilidade, quem somos nós, o que significa ser brasileiro. Agora parece que isso perdeu o vigor. A sua literatura fala dos mecanismos da sociedade brasileira: aquele conflito entre o pai e o filho que têm um filho com a mesma mulher. Potencialmente isso pode acontecer em qualquer lugar do mundo, em qualquer época. Em que medida você diria que a sua literatura é universal e em que medida, apesar disso, é brasileira?

Eu acho que essa história só poderia ter acontecido no Brasil. Mas da mesma forma que eu acho que as histórias do Paul Auster só poderiam ter acontecido em Nova York. Ou que o Desonra do Coetzee, só poderia acontecer na Cidade do Cabo. A história de Antonio só poderia acontecer em São Paulo, inclusive, não é nem no Brasil. Ou que Dostoiévski só poderia acontecer na Rússia. Então eu acho que é brasileira... Tem muitas coisas que podem ser lidas em qualquer lugar do mundo, mas que só poderiam ter acontecido em determinados lugares. Em todos os meus livros - assim como ser mulher é determinante - ser brasileira é muito determinante. $O$ que não quer 
dizer que eu não poderia escrever algo que se passasse em outros países, embora eu acredite que teria dificuldade. Nunca me interessei também por isso.

Parece ser uma tendência na literatura brasileira escrever histórias que acontecem fora do Brasil ou em um lugar sem nome. Por exemplo, os livros de João Paulo Cuenca e Carola Saavedra.

Tem muitos, na verdade. Bernardo Carvalho tem Mongólia, tem O filho da mãe, que se passa na Rússia. Ricardo Lísias tem Anna O. e outras novelas. São uns contos que não se passam em lugar nenhum. E tem dois que eu considero os melhores autores brasileiros: o Nuno Ramos e o Rubens Figueiredo. Do Rubens Figueiredo tudo é muito do Brasil; com o Nuno Ramos, não. Muitas coisas poderiam ser em qualquer lugar do mundo. Eu acho também que as pessoas não leem porque é brasileiro. Às vezes as pessoas leem porque querem saber o que o autor brasileiro está escrevendo, mas não porque querem ler sobre o Brasil. 